\title{
Regulation of Cathepsin D Metabolism in Rabbit Heart
}

\author{
EVIDENCE FOR A ROLE FOR PRECURSOR \\ PROCESSING IN THE CONTROL OF ENZYME ACTIVITY \\ Allen M. Samarel, Edward A. Ogunro, Alan G. Ferguson, Patricia Allenby,
and Michael Lesch, Department of Medicine, Section of Cardiology,
Northwestern University Medical School, Chicago, Illinois 60611
}

A B S T R A C T Production of active lysosomal enzymes may involve limited proteolysis of inactive high molecular weight precursors. Precursor processing potentially regulates lysosomal enzyme activity. To test whether rabbit cardiac cathepsin D is first synthesized as a precursor and whether prolonged fasting (a condition affecting both cathepsin $\mathrm{D}$ and total cardiac protein turnover) influences precursor processing, rates of cathepsin D synthesis and processing were compared in left ventricular slices of control and 3-d-fasted rabbits incubated in vitro with $\left[{ }^{35} \mathrm{~S}\right]$ methionine. ${ }^{35} \mathrm{~S}$-labeled cathepsin $\mathrm{D}$ was isolated by butanol-Triton $\mathrm{X}$ 100 extraction, immunoprecipitation, and dodecyl sulfate-polyacrylamide gel electrophoresis. Total cardiac protein synthesis was measured by tracer incorporation and normalized for differences in precursor pool size by direct measurement of $\left[{ }^{35} \mathrm{~S}\right]$ aminoacyl-tRNA-specific radioactivity. Relative cathepsin $D$ synthetic rates were obtained by comparing ${ }^{35} \mathrm{~S}$ incorporation into cathepsin D with ${ }^{35} \mathrm{~S}$ incorporation into all cardiac proteins. Enzyme processing was assessed in pulsechase experiments and assayed by autoradiography. The results indicate that $(a)$ rabbit cardiac cathepsin $D$ is synthesized as a precursor $(53,000 \mathrm{~mol} \mathrm{wt})$ that is processed to a $48,000-\mathrm{mol}$ wt form, (b) rates of both cathepsin $\mathrm{D}$ and total cardiac protein synthesis are similar in control and fasted rabbits, suggesting that decreased enzyme degradation rather than increased synthesis is responsible for the elevated levels of cardiac cathepsin $\mathrm{D}$ in starvation, and $(c)$ cathepsin $\mathrm{D}$ processing in hearts of fasted animals is incomplete, with accumulation of the precursor during pulse-chase experiments of $6 \mathrm{~h}$ duration. Based upon these results, a three-stage model for the regulation of cathepsin D activity in rabbit heart is proposed.

Received for publication 11 June 1981 and in revised form 11 November 1981.

\section{INTRODUCTION}

Established views concerning the regulation of enzyme activity in animal tissues suggest that the amount of intracellular enzyme is dependent on the opposing processes of continual synthesis and degradation (1). Alterations in enzyme turnover in response to physiologic stimuli are presumed to occur only by the stimuli affecting the rates of these opposing processes. For the study of enzyme turnover, measurements of enzyme activity alone are not sufficient, because factors independent of synthesis and degradation (inhibitors, activators, or activation of previously synthesized inactive enzyme) can alter enzyme activity without affecting enzyme content.

In a previous study (2) we determined that the rate of turnover of rabbit cardiac cathepsin D (EC 3.4.23.5) was decreased by prolonged fasting. Using a sensitive and specific radioimmunoassay, we noted a marked increase in immunoreactive cathepsin $D$ content in the left ventricles of rabbits subjected to fasting for 3-14 d. However, the increased levels of immunoreactive enzyme were greater than the increased levels of enzyme activity observed, resulting in a significant reduction in the specific activity (activity units per microgram of immunoreactive enzyme) of cathepsin D in hearts of fasted animals. These results suggested that factors other than the rates of synthesis and degradation were responsible for the regulation of enzyme activity. In addition, these data were consistent with the results of previous studies $(3,4)$ demonstrating a reduction in the overall rate of cardiac protein degradation during starvation in that a partial block in lysosomal proteolysis may have resulted from the presence of increased amounts of immunoreactive cathepsin D possessing little or no enzyme activity (2).

The existence of a precursor form of the enzyme is one possible mechanism to account for the accumu- 
lation of immunoreactive cathepsin $\mathrm{D}$ with decreased specific activity in the hearts of fasted animals. Regulation of cathepsin D activity, therefore, could be dependent not only on the rates of enzyme synthesis and degradation but also on the rate of precursor activation. Recent evidence from cell-free protein synthesis $(5)$ and cell culture $(5,6)$ experiments has suggested that lysosomal enzymes are initially synthesized as high molecular weight precursors that are processed by limited proteolysis to smaller active enzymes during intracellular transport and packaging. It is not known, however, whether these precursors are present in significant amounts in adult cardiac myocytes in vivo or whether the proteolytic processing of newly synthesized lysosomal enzyme precursors is subject to physiologic regulation.

Based upon our previous observations and those of others, the aims of the present study were threefold: (a) to determine whether cathepsin D exists as two forms with different molecular weights within rabbit myocardium; (b) to compare the rates of synthesis of cathepsin $D$ protein in left ventricular tissue of control and 3-d-fasted rabbits, and $(c)$ to determine whether alterations in the rate of enzyme synthesis and/or processing might account for the increased levels of cardiac immunoreactive cathepsin $\mathrm{D}$ found during prolonged fasting. Data are presented that indicate that the increased amount of cathepsin D protein in hearts of fasted animals results from decreased cathepsin $D$ degradation rather than from increased enzyme synthesis. Moreover, evidence that cathepsin $D$ is present in rabbit heart as a larger molecular weight precursor and that a reduced rate of precursor processing to smaller molecular weight forms occurs in the hearts of fasted animals is reported. These data suggest that the reduced specific activity of cathepsin $D$ noted in hearts of fasted rabbits is due to dilution of the mature enzyme with a larger molecular weight precursor of reduced activity.

\section{METHODS}

Reagents. ${ }^{14} \mathrm{C}$-labeled molecular weight standards were obtained from New England Nuclear, Boston, MA. L$\left[{ }^{35} \mathrm{~S}\right] \mathrm{Methionine},\left[{ }^{3} \mathrm{H}\right]$ dansyl chloride, Dimalume-30, and Soluene-350 were obtained from Amersham Corp., Arlington Heights, IL. CNBr-activated Sepharose 4B was purchased from Pharmacia Fine Chemicals, Piscataway, NJ and prepared according to manufacturer's instructions. Nitrocellulose sheets $(0.45 \mu \mathrm{m})$ were obtained from Bio-Rad Laboratories, Richmond, CA. Sodium dodecyl sulfate (SDS) was obtained from Eastman Organic Chemicals Div., Eastman Kodak Co., Rochester, NY. All other reagents were of the highest analytical grade commercially available and were obtained from Sigma Chemical Co., St. Louis, MO and Scientific Products Div., American Hospital Supply Corp., McGaw Park, IL.

Purification of rabbit cathepsin D. Cathepsin D was purified to homogeneity from rabbit liver and heart as previ- ously described (7). Enzyme activity was assayed by the method of Anson (8), with bovine hemoglobin as substrate.

Preparation of monospecific antibody to cathepsin $D$. Antisera to purified rabbit liver cathepsin D were raised in English short-haired guinea pigs (2). Monospecificity was demonstrated by double immunodiffusion (9), immunoelectrophoresis (9), and crossed immunoelectrophoresis (10) in agarose gels (results not shown).

In immunoprecipitation experiments utilizing soluble monospecific antibody, the immunoglobulin $G$ fraction was partially purified by repeated ammonium sulfate precipitation (to $50 \%$ saturation) followed by dialysis against $50 \mathrm{mM}$ sodium phosphate buffer, pH 7.4.

In immunoadsorption experiments utilizing solid-phase monospecific antibody, guinea pig antibody was further purified by immunoadsorbent affinity chromatography using rabbit liver cathepsin D bound to $\mathrm{CNBr}$-activated Sepharose 4B (11). The purified antibody thus produced was bound to CNBr-activated Sepharose 4B to yield a solid-phase monospecific immunoadsorbent (11).

Both the partially purified soluble monospecific antibody and the solid-phase monospecific immunoadsorbent were titrated in preliminary experiments to determine the amount of antibody necessary to quantitatively precipitate immunoreactive cathepsin D from extracts of rabbit myocardium.

Experimental animals. Male New Zealand White rabbits weighing $\sim 2.0 \mathrm{~kg}$ (Lessers Rabbitry, Union Grove, WI) were used in all experiments. The animals were housed and killed as previously described (2). Control animals received a diet of laboratory chow and water ad lib. Fasted animals were deprived of food but not water for $3 \mathrm{~d}$ before killing.

Tissue incubation system. The hearts from control and fasted animals were rapidly removed, and the left ventricular free walls were dissected free of pericardium, fat, and blood vessels. Slices of the left ventricle $(0.5-1 \mathrm{~mm}$ thick, 4-6 mm long, 30-50 mg wet wt) were prepared with a scalpel and incubated in small Erlenmeyer flasks in a metabolic shaker $\left(37^{\circ} \mathrm{C}\right)$. The flasks were stoppered and two vent holes were constructed to allow the contents to be continuously equilibrated with a gas mixture of $95 \% \mathrm{O}_{2}, 5 \% \mathrm{CO}_{2}$ without bubbling. Krebs-Ringer bicarbonate buffer containing $5 \mathrm{mM}$ glucose ( $4 \mathrm{ml} /$ flask) was used as the incubation medium After a preliminary incubation of $30 \mathrm{~min}$, the Krebs-Ringer bicarbonate buffer was replaced by fresh equilibrated medium supplemented with the appropriate concentration of $\left[{ }^{35} \mathrm{~S}\right]$ methionine. In pulse-chase experiments, the radioactive medium was again replaced with fresh equilibrated medium supplemented with unlabeled methionine. At the end of the incubation period, tissue slices were removed and rapidly washed free of absorbed medium with iced distilled water and homogenized.

Pulse-chase analysis of newly synthesized immunoreactive cathepsin $D$. To characterize the newly synthesized cardiac immunoreactive cathepsin $D$, slices of left ventricular myocardium were incubated in pulse-chase experiments with $500 \mu \mathrm{Ci}$ of $\left[{ }^{35} \mathrm{~S}\right]$ methionine per flask $(1,000 \mathrm{Ci} / \mathrm{mmol}$; final concentration, $125 \mathrm{nM})$. After a pulse of $1 \mathrm{~h}$, the radioactive media were removed and replaced with fresh equilibrated media supplemented with $5 \mathrm{mM}$ methionine. At this point half of the tissue slices from each flask were homogenized in $3.5 \mathrm{ml}$ of $20 \mathrm{mM}$ sodium borate buffer, $\mathrm{pH}$ 8.4, containing $150 \mathrm{mM} \mathrm{NaCl}, 270 \mathrm{mM}$ l-butanol and $2 \mathrm{~g}$ of Triton X-100 per liter. ${ }^{1}$ The remaining slices were incu-

${ }^{1}$ As stated in our previous report (2) 1-butanol and Triton $\mathrm{X}-100$ at these concentrations allowed the solubilization of 95-100\% of the total cathepsin D enzyme activity present in the homogenates. 
bated an additional $5 \mathrm{~h}$ in the presence of unlabeled methionine $(5 \mathrm{mM})$ before homogenization. The homogenates were centrifuged at $100,000 \mathrm{~g}$ for $60 \mathrm{~min}$, and the supernatant fractions were filtered through $0.22-\mu \mathrm{m}$ filters on scintered glass supports to remove suspended lipids. The supernatant extracts were then immunoadsorbed with anticathepsin $\mathrm{D}$ solid-phase immunoadsorbent. After gentle mixing for $48 \mathrm{~h}$ at $4^{\circ} \mathrm{C}$, the Sepharose beads were washed by repeated suspension and repelleting at $10,000 \mathrm{~g}$ with homogenization buffer. After a final wash with $1 \mathrm{mM}$ Tris$\mathrm{HCl}, \mathrm{pH} 6.8$, the immunoadsorbed ${ }^{35} \mathrm{~S}$-labeled cathepsin D was desorbed by suspension in $150 \mu \mathrm{l}$ of $1 \mathrm{mM}$ Tris- $\mathrm{HCl}, \mathrm{pH}$ 6.8 , containing $5 \mathrm{ml}$ of 2-mercaptoethanol and $2 \mathrm{~g}$ of SDS per $100 \mathrm{ml}$, followed by heating to $100^{\circ} \mathrm{C}$ for $5 \mathrm{~min}$. The extracted beads were pelleted by centrifugation, and the supernatant solutions were lyophilized to dryness. The residues were redissolved in aqueous 2 -mercaptoethanol $(5 \mathrm{ml} /$ $100 \mathrm{ml}$ ) and subjected to electrophoresis on horizontal SDSslab gels according to the method of Laemmli (12). After electrophoresis, the separated proteins were transferred to nitrocellulose sheets by electroblotting (13), and the stained, dried electroblots were subjected to autoradiography for 37 d using X-Omat GXR film (Eastman Kodak Co., Rochester, NY). The developed autoradiographs were scanned at 590 $\mathrm{nm}$ with a spectrophotometer (model 25, Beckman Instruments, Inc., Fullerton, CA) to quantify the distribution of precursor and processed forms of this enzyme.

Analysis of ${ }^{35}$ S incorporation. In experiments designed to determine the rate of ${ }^{35} \mathrm{~S}$ incorporation into total cardiac protein (TCP) ${ }^{2}$ and immunoreactive cathepsin $D$, incubated tissue slices were rapidly homogenized in $2-5 \mathrm{ml}$ of cold 50 $\mathrm{mM}$ sodium phosphate buffer, $\mathrm{pH} 7.4$, containing $150 \mathrm{mM}$ $\mathrm{NaCl}, 270 \mathrm{mM}$ 1-butanol, and $2 \mathrm{~g}$ of Triton $\mathrm{X}-100$ per liter. Aliquots $(50 \mu \mathrm{l})$ of the homogenates were removed for determination of protein content (14). In addition, $50-\mu$ l aliquots were removed into $2 \mathrm{ml}$ of trichloroacetic acid $(10 \mathrm{~g} /$ $100 \mathrm{ml}$ ) containing unlabeled methionine $(400 \mathrm{mg} / 100 \mathrm{ml})$. The acid-precipitable protein was analyzed for ${ }^{35} \mathrm{~S}$ incorporation as previously described (15). The homogenates were centrifuged at $100,000 \mathrm{~g}$ for $60 \mathrm{~min}$. The supernatant extracts were filtered as described above, and immunoreactive cathepsin $\mathrm{D}$ was quantitatively precipitated by the addition of soluble monospecific antibody and carrier rabbit liver cathepsin $\mathrm{D}$. After incubation at $4^{\circ} \mathrm{C}$ for $24 \mathrm{~h}$, the immunoprecipitates (containing ${ }^{35} \mathrm{~S}$-labeled cathepsin D) were carefully washed by repeated suspension and repelleting at $3,000 \mathrm{~g}$ in a solution of $50 \mathrm{mM}$ sodium phosphate buffer, $\mathrm{pH}$ 7.4 , containing $150 \mathrm{mM} \mathrm{NaCl}$ and $2 \mathrm{~g}$ of Triton $\mathrm{X}-100$ per liter. The washed immunoprecipitates were dissolved in 100 $\mu l$ of a solution containing $12 \mathrm{mg}$ Tris, $15 \mathrm{mg}$ dithiothreitol, and $10 \mathrm{mg} \mathrm{SDS} / \mathrm{ml}$, followed by heating to $100^{\circ} \mathrm{C}$ for $2 \mathrm{~min}$. SDS-polyacrylamide gel electrophoresis was performed on cylindrical gels $(8 \times 90 \mathrm{~mm})$ according to the method of Weber and Osborn (16). After electrophoresis and staining the gels were sliced with a wire gel slicer into $1-\mathrm{mm}$ sections. Each gel section was solubilized in $500 \mu \mathrm{l}$ of water and 500 $\mu \mathrm{l}$ of tissue solubilizer (Soluene-350) at $25^{\circ} \mathrm{C}$ for $18 \mathrm{~h}$. Scintillation fluid (10 ml of Dimalume-30) was added, and the solubilized gel slices were counted for ${ }^{35} \mathrm{~S}$ radioactivity in a scintillation spectrometer (Tricarb model 3375, Packard Instrument Co., Inc., Downers Grove, IL). Counts obtained were corrected for background and for quenching with external standards.

Analysis of $\left[{ }^{35}\right.$ S $]$ aminoacyl-tRNA-specific radioactivity. In separate experiments designed to determine the specific ra-

${ }^{2}$ Abbreviation used in this paper: TCP, total cardiac protein. dioactivity of the $\left[{ }^{35} \mathrm{~S}\right] \mathrm{aminoacyl}-\mathrm{tRNA}$ pools serving as precursors for protein synthesis, incubated tissue slices from control and fasted rabbits were homogenized in $3 \mathrm{ml}$ of 250 $\mathrm{mM}$ sodium cacodylate buffer, $\mathrm{pH} 6.8$, containing $10 \mathrm{~g}$ of SDS per liter. Aliquots of homogenates were removed for determination of ${ }^{35} \mathrm{~S}$ incorporation into TCP and for protein content, as described above. Amino acids acylated to tRNA were isolated by the method of Airhart et al. (17). ${ }^{[35}$ S]Methionyl-tRNA- and ${ }^{35}$ S $]$ cysteinyl-tRNA-specific radioactivities were determined by double-label radioassay of ${ }^{3} \mathrm{H}$-dansylation derivatives of $\left[{ }^{35} \mathrm{~S}\right]$ methionine sulfone and $\left[{ }^{35}\right.$ S]cysteic acid by a method developed by our laboratory (18). Rates of TCP synthesis in hearts of control and fasted rabbits were obtained by dividing the rates of ${ }^{35} \mathrm{~S}$ incorporation into acid-precipitable TCP by the sum of the specific radioactivities of the $\left[{ }^{35} \mathrm{~S}\right]$ methionyl-tRNA and $\left[{ }^{35} \mathrm{~S}\right]$ cysteinyltRNA pools (18).

Calculation of immunoreactive cathepsin $D$ synthetic rate. To obtain relative rates of cathepsin $\mathrm{D}$ synthesis, the rate of ${ }^{35} \mathrm{~S}$ incorporation into immunoreactive cathepsin $\mathrm{D}$ was compared to the rate of ${ }^{35} \mathrm{~S}$ incorporation into TCP of tissue homogenates from fed and fasted animals. The ratios obtained are based upon the assumption that all proteins are synthesized from the same precursor amino acid pool and that ${ }^{35} \mathrm{~S}$ incorporation into TCP represents an integration of the ${ }^{35}$ S] aminoacyl-tRNA precursor pool specific radioactivity (1). This method provides information only on the relative rate of enzyme synthesis compared to the rate of synthesis of all cellular proteins. Alterations in these ratios could be caused by simultaneous changes in both cathepsin $D$ and TCP synthesis. To obtain more definitive information regarding the absolute rate of cathepsin $D$ synthesis, rates of TCP synthesis were compared by direct measurement of ${ }^{35}$ S]aminoacyl-tRNA-specific radioactivity and the rate of ${ }^{35} \mathrm{~S}$ incorporation into TCP under identical incubation conditions.

Because of metabolic conversion of methionine to cysteine during tissue incubation, both $\left[{ }^{35}\right.$ S $]$ methionyl-tRNA- and $\left[{ }^{35}\right.$ S $]$ cysteinyl-tRNA-specific radioactivities were measured. Despite the metabolism of methionine by cardiac tissue, however, ${ }^{35} \mathrm{~S}$ radioactivity into protein could have only been derived from $\left[{ }^{35}\right.$ S $]$ methionyl-tRNA and $\left[{ }^{35}\right.$ S cysteinyl-tRNA. Because conversion of methionine to cysteine was identical in control and fasted tissues (see Table I) and because the ratio of cysteine to methionine residues in newly synthesized cardiac protein for control and fasted animals can be assumed to be constant, rates of TCP synthesis were proportional to the ratio of ${ }^{35} \mathrm{~S}$ incorporation and the sum of the specific radioactivities of $\left[{ }^{35}\right.$ S $]$ methionyl-tRNA and $\left[{ }^{35} \mathrm{~S}\right] \mathrm{cys}$ teinyl-tRNA precursor pools (18).

\section{RESULTS}

Immunotitration of monospecific antibody preparations. Both the soluble monospecific antibody and the solid-phase monospecific immunoadsorbent were capable of quantitative precipitation of cathepsin D from extracts of rabbit myocardium. In subsequent experiments, monospecific antibody was added in excess to the amount of enzyme activity present in, or added to, tissue extracts to isolate all of the immunoreactive cathepsin D. Complete immunoprecipitation and recovery of enzyme were routinely evaluated by the absence of cathepsin $D$ activity in supernatant fractions obtained after immunoprecipitation and washing. 
Characterization of newly synthesized immunoreactive cathepsin $D$. Autoradiographs obtained from normal rabbit left ventricular slices incubated for $4 \mathrm{~h}$ with ${ }^{35}$ S $]$ methionine showed that the immunoreactive enzyme consisted of two forms of 53,000 and 48,000 mol wt (Fig. 1). When the tissue slices were incubated in pulse-chase experiments, nearly complete conversion of the labeled 53,000 -mol wt form to the 48,000 mol wt species occurred during the time-course of incubation (Fig. 1). The 48,000-mol wt form of cathepsin $D$ comigrated with the purified enzyme isolated from both rabbit liver and heart. No further processing of the rabbit enzyme to smaller molecular weight forms was detected in these experiments. To obtain quantitative data regarding the rates of total immunoreactive cathepsin D synthesis in tissue slices from control and 3-d-fasted rabbits, ${ }^{35} \mathrm{~S}$ incorporation into both the 53,000 - and 48,000-mol wt forms of cathepsin D was examined.

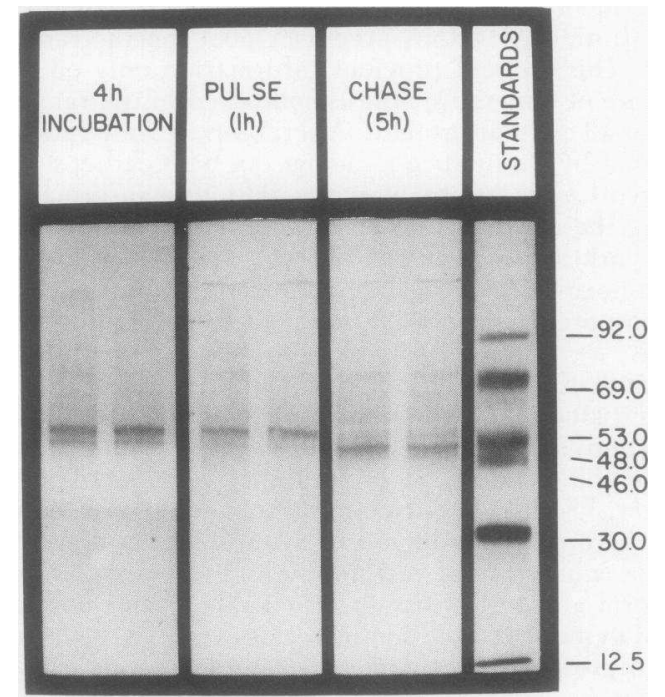

FIgURE 1 Characterization of newly synthesized cathepsin $D$ by autoradiography. Left ventricular tissue slices were incubated in Krebs-Ringer bicarbonate buffer ( $4 \mathrm{ml} / \mathrm{flask}$ ) containing $500 \mu \mathrm{Ci}$ of $\left[{ }^{35} \mathrm{~S}\right]$ methionine $(1,000 \mathrm{Ci} / \mathrm{mmol}$; final concentration, $125 \mathrm{nM}$ ). Immunoreactive cathepsin $D$ was isolated by butanol-Triton X-100 extraction, immunoadsorption, and SDS-polyacrylamide gel electrophoresis. After a 4-h incubation in the presence of $\left.{ }^{35} \mathrm{~S}\right]$ methionine, newly synthesized cathepsin D migrated as two forms of mol wt 53,000 and 48,000. When slices were incubated for $1 \mathrm{~h}$ (pulse), most of the ${ }^{35} \mathrm{~S}$-labeled enzyme had an apparent mol wt of 53,000. When tissue slices were pulsed for $1 \mathrm{~h}$ followed by a 5 -h chase in unlabeled medium supplemented with 5 $\mathrm{mM}$ methionine (chase), the ${ }^{35} \mathrm{~S}$-labeled enzyme migrated with an apparent mol wt of 48,000. Apparent molecular weights were determined from semilogarithmic plots using ${ }^{14} \mathrm{C}$-methylated standards of phosphorylase B $(92,000)$, bovine serum albumin $(69,000)$, ovalbumin $(46,000)$, carbonic anhydrase $(30,000)$, and cytochrome $c(12,500)$. Numbers for standards indicate molecular weight $\times 10^{-3}$
Validation of incubation system. Using the tissue incubation system described in Methods, ${ }^{35} \mathrm{~S}$ incorporation into acid-precipitable TCP (for both control and 3-d-fasted rabbits) was linear for up to $4 \mathrm{~h}$ (Fig. $2 \mathrm{~A}$ ). In addition, ${ }^{35} \mathrm{~S}$ incorporation into TCP of both control and fasted animals increased in proportion to the concentration of $\left[{ }^{35}\right.$ S $]$ methionine added to the incubation medium (Fig. 2 B). ${ }^{35} \mathrm{~S}$ incorporation into TCP of control hearts was consistently greater than that into fasted tissue, irrespective of $\left[{ }^{35} \mathrm{~S}\right]$ methionine concentration or the length of incubation.

Relative cathepsin $D$ synthetic rates. Left ventricular slices incubated for $4 \mathrm{~h}$ in the presence of $\left[{ }^{35}\right.$ S $]$ methionine $(165 \mu \mathrm{Ci} /$ flask; $1,000 \mathrm{Ci} / \mathrm{mmol}$; final concentration, $41 \mathrm{nM}$ ) were used for measurements of relative immunoreactive cathepsin $D$ synthetic rates. Immunoprecipitates resulting from the reaction of ${ }^{35} \mathrm{~S}$ labeled cardiac extracts from control and 3-d-fasted rabbits and soluble monospecific antibody to cathepsin D were examined by SDS-polyacrylamide gel electrophoresis (Fig. 3). Although multiple bands were visible on the gels after staining, a broad region of ${ }^{35} \mathrm{~S}$ radioactivity spanning the area coinciding with 53,00048,000 mol wt was detected after the gels were sectioned and counted. Minor ${ }^{35} \mathrm{~S}$-labeled peaks at 85,000 and $100,000 \mathrm{~mol} w \mathrm{w}$ were frequently observed and probably represented nonspecifically adsorbed proteins. The amount of radioactivity in the 53,00048,000-mol wt peak (that included both molecular weight forms of the enzyme) was used to calculate the rate of cathepsin $D$ synthesis.

${ }^{35} \mathrm{~S}$ incorporation into cardiac cathepsin D isolated from the hearts of 3-d-fasted animals was significantly decreased as compared with control tissue (10.5 \pm 0.5 vs. $26.5 \pm 4.6 \mathrm{pCi} / \mathrm{mg}$ TCP per $\mathrm{h}$ for fasted and control animals, respectively, $P<0.01$, Table I). ${ }^{35} \mathrm{~S}$ incorporation into acid-precipitable TCP was also significantly depressed in fasted animals (76.4 46.4 vs. $155 \pm 22$ $\mathrm{nCi} / \mathrm{mg}$ TCP per $\mathrm{h}$ for fasted and control animals, respectively, $P<0.001$, Table I). By comparing the rate of ${ }^{35} \mathrm{~S}$ incorporation into immunoreactive cathepsin D with the rate of ${ }^{35} \mathrm{~S}$ incorporation into all cellular proteins, a measure of relative cathepsin D synthesis was obtained. Utilizing these measurements, the relative rate of cardiac cathepsin D synthesis was found to be slightly depressed during fasting $(1.39 \pm 0.07$ $\times 10^{-4}$ vs. $1.70 \pm 0.10 \times 10^{-4}$ for fasted and control rabbits, respectively, $P<0.05$ ). These results suggest that the observed differences in ${ }^{35} \mathrm{~S}$ incorporation into immunoreactive cathepsin $\mathrm{D}$ were not solely due to differences in $\left[{ }^{35} \mathrm{~S}\right]$ aminoacyl-tRNA-specific radioactivity, assuming that all proteins (including cathepsin D) were synthesized from the same amino acid pool.

To verify these results and to determine whether an absolute decrease in cardiac cathepsin $D$ synthesis oc- 

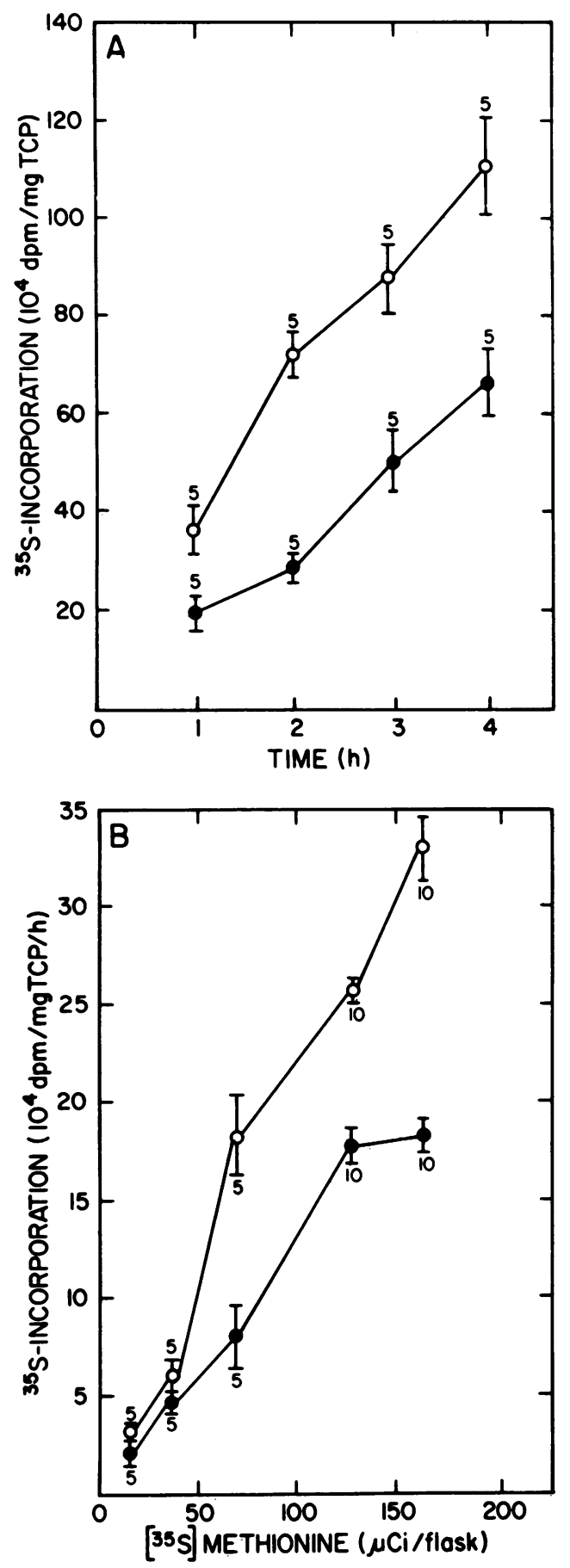

FIgURE 2 Validation of tissue incubation system for ${ }^{35} \mathrm{~S}$ incorporation into TCP. (A) Left ventricular tissue slices from control and 3-d-fasted rabbits were incubated in KrebsRinger bicarbonate buffer containing $135 \mu \mathrm{Ci}$ of $\left[{ }^{35}\right.$ S $]$ methionine $(1,000 \mathrm{Ci} / \mathrm{mmol}$; final concentration, $34 \mathrm{nM})$. Tissue slices were removed at $1,2,3$, and $4 \mathrm{~h}$, and ${ }^{35} \mathrm{~S}$ incorporation into $10 \%$ trichloroacetic acid-precipitable TCP was measured. Data are presented as the mean \pm SEM for each group of five animals examined. $O$, control (mean $\pm S E M)$;

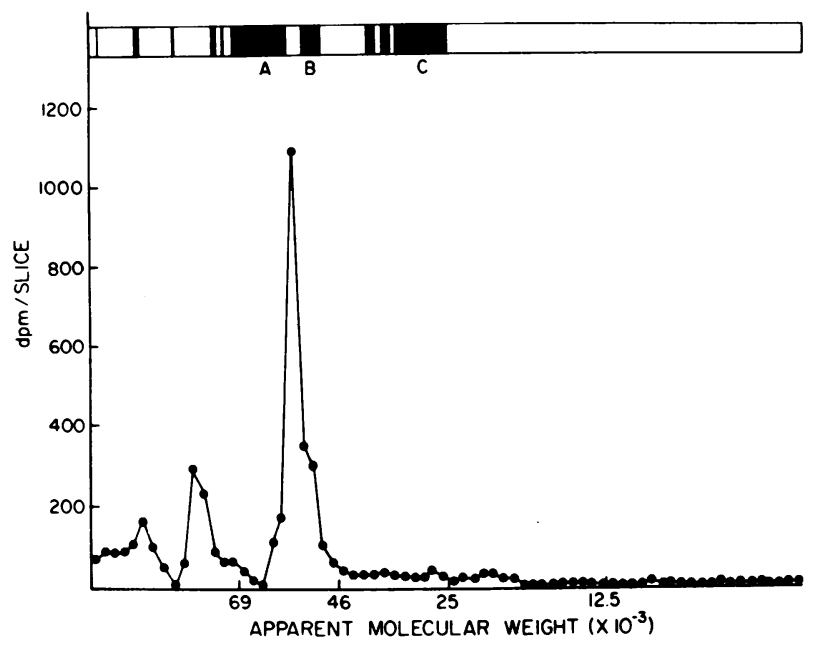

Figure $3{ }^{35} \mathrm{~S}$ incorporation into total immunoreactive cathepsin D. Left ventricular tissue slices from control and 3$\mathrm{d}$-fasted rabbits were incubated for $4 \mathrm{~h}$ in medium containing $165 \mu \mathrm{Ci}$ of $\left[{ }^{35} \mathrm{~S}\right]$ methionine per flask $(1,000 \mathrm{Ci} / \mathrm{mmol}$; final concentration, $41 \mathrm{nM}$ ). Immunoreactive cathepsin $D$ was quantitatively isolated by butanol-Triton X-100 extraction, immunoprecipitation with soluble monospecific antibody and purified carrier cathepsin D, and SDS-polyacrylamide gel electrophoresis. After staining, the gels (as schematically depicted at the top of the figure) were sliced into $1-\mathrm{mm}$ sections and counted for ${ }^{35} \mathrm{~S}$ radioactivity. The amount of radioactivity in the peak spanning 53,000-48,000 mol wt was used to calculate ${ }^{35} \mathrm{~S}$ incorporation into immunoreactive cathepsin D. Apparent molecular weights were determined from semilogarithmic plots of simultaneously separated standards of bovine serum albumin, ovalbumin, $\alpha$-chymotrypsinogen (mol wt 25,500) and cytochrome $c$. The heaviest-staining bands on the gels were IgG heavy chain $(A)$, purified rabbit cathepsin D $(B)$, and IgG light chain $(C)$.

curred during starvation, rates of ${ }^{35} \mathrm{~S}$ incorporation into TCP under identical incubation conditions were normalized for differences in precursor pool specific radioactivity.

Total cardiac protein synthetic rates. As in the experiments described above, ${ }^{35} \mathrm{~S}$ incorporation into acid-precipitable TCP of 3-d-fasted animals was significantly decreased as compared with controls $(91.4 \pm 4.1$ vs. $145 \pm 9.1 \mathrm{nCi} / \mathrm{mg} \mathrm{TCP} / \mathrm{h}$ for fasted and control animals, respectively, $P<0.001$, Table II). However, both the $\left[{ }^{35}\right.$ S $]$ methionyl-tRNA- and $\left[{ }^{35}\right.$ S $]$ cysteinyl-tRNA-specific radioactivities were also decreased in tissue slices from fasted animals. When normalized for these differences in precursor pool-specific

-, 3-d fasted (mean $\pm S E M$ ). (B) Tissue slices from control and 3-d-fasted rabbits were incubated for $4 \mathrm{~h}$ in medium containing $10,20,70,135$, and $165 \mu \mathrm{Ci}$ of $\left[{ }^{35} \mathrm{~S}\right]$ methionine per flask $(1,000 \mathrm{Ci} / \mathrm{mmol}$; final concentrations, $2.5,5,18$, 34 , and $41 \mathrm{nM}$, respectively). Rates of ${ }^{35} \mathrm{~S}$ incorporation into acid-precipitable TCP was measured and expressed as in $A$ for each group of 5-10 animals examined. 
TABLE I

Relative Immunoreactive Cathepsin D Synthetic Rates

\begin{tabular}{lccc}
\hline & $\begin{array}{c}\text { sss } \\
\text { ss } \text { incorporation } \\
\text { into Cathepsin } \mathrm{D}\end{array}$ & $\begin{array}{c}\text { incorporation } \\
\text { into TCP }\end{array}$ & $\begin{array}{c}\text { Relative cathepsin D } \\
\text { synthesis }\end{array}$ \\
\hline & $p C i / m g T C P / h$ & $n C i / m g ~ T C P /$ & \\
& $26.5 \pm 4.6$ & $155 \pm 22$ & $\times 10^{+4}$ \\
Control $(n=5)$ & $10.5 \pm 0.5$ & $76.4 \pm 6.4$ & $1.70 \pm 0.10$ \\
3-d-fasted $(n=5)$ & $P<0.001$ & $P<0.01$ & $1.39 \pm 0.07$ \\
& & $P<0.05$ \\
\hline
\end{tabular}

Relative rates of cathepsin D synthesis in control and 3-d-fasted animals were obtained by dividing the rate of ${ }^{35} \mathrm{~S}$ incorporation into immunoreactive cathepsin $\mathrm{D}$ by the rate of ${ }^{35} \mathrm{~S}$ incorporation into total cellular protein. Data are expressed as the mean $\pm \mathrm{SEM}$ for each group of five animals. $P$ values were obtained by comparison of data from the 3-d-fasted animals with data obtained from the control group by Student's test for unpaired data.

radioactivity, rates of TCP synthesis were statistically identical in control and fasted rabbits (Table II). These results are in agreement with those of Rannels et al. (19), in which no difference in the rate of TCP synthesis was observed in isolated perfused rat hearts obtained from control and 2-d-fasted animals. Referring to the results obtained for relative cathepsin D synthetic rates in control and fasted animals (Table I), the absolute rate of cathepsin $\mathrm{D}$ synthesis must have been similar (or slightly decreased) in fasted hearts as compared with controls, because the rates of TCP synthesis were identical.

To further compare the events of cardiac cathepsin D synthesis in control and fasted animals, rates of enzyme processing were examined by pulse-chase autoradiography.

Comparative rates of immunoreactive cathepsin $D$ processing. Rates of processing of cardiac cathepsin D from control and 3-d-fasted animals were qualitatively compared by pulse-chase autoradiography (Fig. 4). As in control tissue, immunoreactive cathepsin D from hearts of fasted rabbits was initially synthesized as a precursor $(53,000 \mathrm{~mol} \mathrm{wt})$. The $53,000-\mathrm{mol} \mathrm{wt}$ form was also converted to the 48,000 -mol wt species during the time-course of incubation. However, interconversion of the two molecular weight forms by tissue slices from fasted animals appeared to be incomplete. After a $1-h$ pulse and 5 -h chase, nearly all of the ${ }^{35} \mathrm{~S}$ labeled cathepsin $\mathrm{D}$ from control tissue slices migrated with an apparent molecular weight of 48,000 , whereas a major portion of the ${ }^{35} \mathrm{~S}$-labeled enzyme from fasted animals was still present as the 53,000 -mol wt form. These results were confirmed by densitometric scanning of the autoradiographs (Table III).

TABLE II

Total Cardiac Protein Synthesis Rates Normalized for $\left[{ }^{35}\right.$ S A minoacyl-tRNA-specific Radioactivity

\begin{tabular}{|c|c|c|c|c|c|}
\hline & $\begin{array}{c}\text { ss } \\
\text { incorporation } \\
\text { into TCP }\end{array}$ & $\mathrm{SA}_{\mathrm{Mat}} \mathbf{*}^{*}$ & $\mathrm{SA}_{\mathrm{Cyy}} \mathrm{t}$ & $\mathrm{SA}_{\mathrm{Cyz}_{\mathrm{y}}} / \mathrm{SA}_{\mathrm{Met}}$ & TCP synthetic rate \\
\hline & $n C i / m g T C P / h$ & $p C i / p m o l$ & $p C i / p m o l$ & & RS $n m o l / m g T C P / h$ \\
\hline Control $(n=10)$ & $145 \pm 9.1$ & $13.2 \pm 1.3$ & $3.23 \pm 0.6$ & $0.26 \pm 0.06$ & $9.7 \pm 1.4$ \\
\hline \multirow[t]{2}{*}{ 3-d-fasted $(n=10)$} & $91.4 \pm 4.1$ & $9.09 \pm 1.4$ & $2.23 \pm 0.3$ & $0.26 \pm 0.04$ & $9.7 \pm 1.4$ \\
\hline & $P<0.001$ & $P<0.05$ & $P<0.10$ & NS ${ }^{\prime \prime}$ & NS \\
\hline
\end{tabular}

Rates of total cardiac protein synthesis in left ventricular tissue slices from control and 3-d-fasted rabbits were obtained by comparing the rate of ${ }^{35} \mathrm{~S}$ incorporation with the sum of the $\left[{ }^{35} \mathrm{~S}\right]$ methionyl-tRNA- and $\left[{ }^{35} \mathrm{~S}\right]$ cysteinyl-tRNA-specific radioactivities. Data are expressed as the mean \pm SEM for each group of 10 animals. $P$ values were obtained as in Table $I$.

- $\left({ }^{35}\right.$ S)Methionyl-tRNA specific radioactivity

I $\left.{ }^{35} \mathrm{~S}\right)$ Cysteinyl-tRNA specific radioactivity

$\$$ A constant equal to $\left(\mathbf{S A}_{\mathrm{Cys}} / \mathrm{SA}_{\text {Met }}+1\right) /\left[\left(\mathbf{K}_{1}\right)\left(\mathbf{S A}_{\mathrm{Cys}}\right) / \mathrm{SA}_{\mathrm{Met}}+\mathbf{K}_{2}\right]$, where $\mathbf{K}_{1}$ and $\mathbf{K}_{2}$ are the number of picomoles of cysteine and methionine per picomole of newly synthesized TCP, respectively.

"Not significant. 


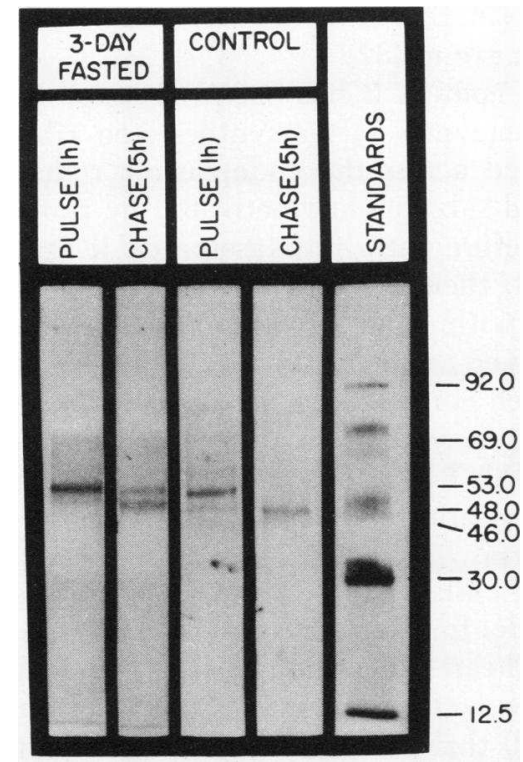

Figure 4 Pulse-chase autoradiography of cardiac cathepsin $D$ from control and 3-d-fasted rabbits. Immunoreactive cathepsin D from control and 3-d-fasted rabbits was isolated from left ventricular tissue slices incubated in pulse-chase experiments, as in Fig. 1. Rates of cathepsin D processing were compared by the conversion of the $53,000-\mathrm{mol}$ wt precursor to the 48,000 -mol wt enzyme during the time-course of incubation. Incomplete processing of the enzyme from fasted rabbits is apparent from the persistence of the $53,000-\mathrm{mol}$ wt precursor after a 5 -h chase.

\section{DISCUSSION}

The results described in this report demonstrate that newly synthesized rabbit cardiac cathepsin D exists as two forms, differing in molecular weight. The larger form (mol wt 53,000) is converted to the smaller form (mol wt 48,000) during the 6-h time period of observation. Our results agree well with those of Erikson and Blobel (5) and Hasilik and Neufeld (6), who demonstrated evidence of cathepsin $\mathrm{D}$ processing in cell monolayers of porcine kidney and human skin fibroblasts, respectively. The molecular weight data presented are based upon the relative mobilities in SDSpolyacrylamide gels and are therefore subject to error due to the frequent aberrant migration of glycoproteins (such as cathepsin D) under these conditions (17). It appears unlikely, however, that changes in the degree of glycosylation of the cathepsin D molecule could account for the large difference in apparent molecular weight between the two enzyme forms. Rather, these results are more consistent with limited proteolysis and removal of a peptide fragment during enzyme processing. In addition, both the human (6) and porcine (5) enzyme underwent further fragmentation into two polypeptide chains during longer pulsechase experiments. Although no further processing of
TABLE III

Distribution of Precursor and Processed Forms of Cathepsin D by Pulse-Chase Autoradiography

\begin{tabular}{|c|c|c|}
\hline & $\begin{array}{l}\text { \% Cathepsin D } \\
\text { precursor } \\
\text { (mol wt } 53,000)\end{array}$ & $\begin{array}{l}\text { \% Cathepsin D } \\
\text { (mol wt 48,000) }\end{array}$ \\
\hline Control, 1-h pulse $(n=8)$ & $79.1 \pm 9.9$ & $20.9 \pm 9.9$ \\
\hline 3-d-fasted, l-h pulse $(n=6)$ & $\begin{array}{l}80.2 \pm 9.2 \\
\mathrm{NS}^{\bullet}\end{array}$ & $\begin{array}{l}19.8 \pm 9.2 \\
\quad \text { NS }\end{array}$ \\
\hline $\begin{array}{l}\text { Control, l-h pulse and } 5-\mathrm{h} \\
\text { chase }(n=8)\end{array}$ & $16.8 \pm 9.7$ & $83.2 \pm 9.7$ \\
\hline $\begin{array}{l}\text { 3-d-fasted, l-h pulse and } 5-h \\
\text { chase }(n=6)\end{array}$ & $\begin{array}{l}40.8 \pm 10 \\
P<0.001\end{array}$ & $\begin{array}{l}59.2 \pm 10 \\
P<0.001\end{array}$ \\
\hline
\end{tabular}

Pulse and pulse-chase autoradiographs of cardiac cathepsin D from control and 3-d-fasted rabbits were examined in a scanning densitometer. Distribution of cathepsin D precursor and processed forms was determined by planimetry. Percentage of the total measured area (corresponding to both forms of the enzyme) are given as mean $\pm \mathrm{SD}$. $P$ values were obtained as in Table $\mathrm{I}$.

- Not significant.

the rabbit enzyme was noted in the present study, nor were split forms of cathepsin D detected in highly purified preparations of rabbit liver and cardiac cathepsin $D(2)$, these results suggest that a protease is at least partly responsible for rabbit cathepsin $\mathrm{D}$ processing.

Second, we sought to determine whether increased synthesis or decreased degradation of immunoreactive cathepsin D was the cause for the increased levels of enzyme protein found in the left ventricles of fasted rabbits (2). When ${ }^{35} \mathrm{~S}$-labeled amino acid incorporation into total immunoreactive cathepsin $\mathrm{D}$ was compared with that of all cellular proteins, cathepsin $D$ synthesis was slightly depressed during fasting. Absolute rates of cathepsin D synthesis were inferred from data comparing rates of TCP synthesis normalized for differences in $\left[{ }^{35}\right.$ S $]$ aminoacyl-tRNA-specific radioactivity. From these experiments, we conclude that the intrinsic ability of cardiac tissue to synthesize protein (including cathepsin D) is not dramatically affected by prolonged fasting and that maintenance of increased levels of cardiac cathepsin D during starvation results from decreased rates of enzyme degradation of this specific enzyme. Certain reservations about these conclusions must, however, be considered.

First, since the loss of cardiac mass during starvation occurs over long periods of time as compared with the relatively short in vitro incubations used in this study, a small but persistent decrease in protein synthesis not detectable by our assay system (e.g., 5-10\%) could exist and be responsible for starvation-induced cardiac atro- 
phy. Second, because starvation may alter the pattern of myocardial protein synthesis independent of the rate of synthesis, i.e., more or less methionine-rich or methionine-poor proteins may be synthesized during starvation, rates of synthesis calculated from incorporation data with a single labeled amino acid may be less quantitative than desired. These limitations notwithstanding, the data presented in Tables I and II indicate that the rates of protein synthesis in hearts of starved and control animals if not identical are not dramatically different.

Finally, we sought to find the cause of the reduced specific activity of cardiac cathepsin D during prolonged fasting (2). In pulse-chase experiments we noted incomplete processing of the precursor form of cathepsin D in the hearts of fasted rabbits. Similarly, Erikson and Blobel (5) have found evidence for the persistence of cathepsin D precursor in cell culture during chase periods of up to $47 \mathrm{~h}$. In addition, Hasilik and Neufeld have provided indirect evidence for the absence of cathepsin D activity of the larger precursor molecule isolated from the medium of fibroblast cell cultures of patients with I-cell disease $(6,20)$. If the higher molecular weight form of rabbit cardiac cathepsin $D$ is indeed inactive, then the accumulation of this immunoreactive (but enzymatically inactive) form of the enzyme would readily account for the results of our previous radioimmunoassay experiments (2). This interpretation is, however, inferential due to kinetic considerations.

A 1- to 4-h delay in the processing of an enzyme with a $t_{1 / 2}>24 \mathrm{~h}$ might not affect tissue enzyme activity unless the delay in processing persists for longer periods of time. Experimental proof for such a prolonged delay requires pulse-chase incubations of $15-20 \mathrm{~h}$. Because the in vitro left ventricular slice preparation used in the present study is not metabolically stable past 6 $h$, definitive evaluation of this problem will require in vivo pulse-chase experiments.

Evidence for the accumulation of cardiac cathepsin $\mathrm{D}$ in extralysosomal sites during prolonged fasting has been obtained using biochemical (21), immunohistochemical (21), and electron immunocytochemical techniques (22). Starvation produced a significant increase in total as well as nonsedimentable cathepsin D activity in the hearts of rabbits and mice (21). In addition, immunohistochemical localization of cathepsin D using a fluorescein-labeled antibody produced a diffuse cellular staining pattern reminiscent of the pattern in ischemic myocytic necrosis. More definitive experiments using a horseradish peroxidase-conjugated indirect antibody clearly showed that, although the enzyme was localized to lysosomes in both control and fasted animals, there was a considerable amount of cathepsin D within the sarcoplasmic reticulum of the latter group (22).

In this context it has been suggested (23) that lysosomal enzymes (after synthesis on ribosomes) are transported across the endoplasmic reticulum membrane and subsequently activated by proteolytic processing before entry into lysosomes. If this hypothesis is correct, then it seems likely that the cathepsin D detected within the sarcoplasmic reticulum of hearts from starved animals (22) may represent morphologic data which correlates to the biochemical evidence of decreased enzyme processing described in this report. Proof of this hypothesis must, however, await subcellular localization studies of the precursor and processed forms.

On the basis of these results, we propose a threestage model for the regulation of cathepsin $\mathrm{D}$ activity in rabbit heart. According to this model, cathepsin D is initially synthesized as a 53,000 -mol wt precursor (inactive?) that is subsequently processed into an active 48,000-mol wt form and finally degraded into amino acids. Because the rate of cardiac cathepsin D synthesis is similar in control and fasted animals, fasting results in decreased enzyme processing and possibly in decreased enzyme degradation, leading to the accumulation of both active and precursor forms of the enzyme. Fasting would, therefore, lead to increased cathepsin $\mathrm{D}$ activity but an overall reduction in the specific activity of the enzyme due to dilution of the active enzyme pool with the larger molecular weight precursor of reduced or no activity. This model places equal importance on the rates of enzyme synthesis, proteolytic processing, and degradation in the ultimate regulation of cathepsin $D$ activity in the heart. The model does not, however, preclude the possibility that each stage of the model is under independent control.

In conclusion, our results may aid in the interpretation of previous studies relating measurements of cathepsin D activity to the in vitro rate of cardiac protein degradation during prolonged fasting $(3,4)$. Whereas total cathepsin $\mathrm{D}$ activity and lysosomal lability were increased in the hearts of fasted rats, the effect of starvation on the intrinsic proteolytic capacity of this tissue was opposite to that expected on the basis of these lysosomal alterations. The present study demonstrates that measurements of enzyme activity alone do not reflect the complexity of cardiac cathepsin D metabolism during starvation. Perhaps a better indicator of the state of cardiac lysosomal proteolysis during physiologic interventions may be the evaluation of the rate of cathepsin D precursor processing, or cathepsin $\mathrm{D}$ specific activity as determined by radioimmunoassay. 


\section{ACKNOWLEDGMENTS}

These studies were supported in part by U. S. Public Health Service grant NHLBI-19648 and a grant from the Oppenheimer Family Foundation. Dr. Samarel was a recipient of an Owen L. Coon Foundation fellowship at Northwestern University during the time that these studies were performed.

\section{REFERENCES}

1. Schimke, R. T. 1975. Methods for analysis of enzyme synthesis and degradation in animal tissues. In Methods in Enzymology. B. W. O'Malley and J. C. Hardman, editors. Academic Press, Inc., New York. 40: 241-273.

2. Samarel, A. M., E. A. Ogunro, A. G. Ferguson, P. Allenby, and M. Lesch. 1981. Rabbit cardiac immunoreactive cathepsin $D$ content during starvation-induced atrophy. Am. J. Physiol. 240: H222-H228.

3. Crie, J. S., C. F. Sanford, and K. Wildenthal. 1980. Influence of starvation and refeeding on cardiac protein degradation in rats. J. Nutr. 110: 22-27.

4. Curfman, G. D., D. S. O'Hara, B. E. Hopkins, and T. W. Smith. 1980. Suppression of myocardial protein degradation in the rat during fasting: effects of insulin, glucose and leucine. Circ. Res. 46: 581-589.

5. Erikson, A. H., and G. Blobel. 1979. Early events in the biosynthesis of the lysosomal enzyme cathepsin D. J. Biol. Chem. 254: 11771-11774.

6. Hasilik, A., and E. F. Neufeld. 1980. Biosynthesis of lysosomal enzymes in fibroblasts: synthesis as precursors of higher molecular weight. J. Biol. Chem. 255: 49374945.

7. Ogunro, E. A., A. G. Ferguson, and M. Lesch. 1980. A kinetic study of the $\mathrm{pH}$ optimum of canine cardiac cathepsin D. Cardiovasc. Res. 14: 254-260.

8. Anson, M. L. 1938. The estimation of pepsin, trypsin, papain and cathepsin with hemoglobin. J. Gen. Physiol. 22: 79-89.

9. Ochterlony, O., and L. A. Nilsson. 1973. Immunodiffusion and immunoelectrophoresis. In Handbook of Experimental Immunology. D. M. Weir, editor. Blackwell, Oxford. 2nd. ed. 19.1-19.39.

10. Laurell, C.-B. 1965. Antigen-antibody crossed electrophoresis. Anal. Biochem. 9: 358-361.

11. Thomas, P. E., D. Korzeniowski, D. Ryan, and W. Levin.
1979. Preparation of monospecific antibodies against two forms of rat liver cytochrome P-450 and quantitation of these antigens in microsomes. Arch. Biochem. Biophys. 192: 524-532.

12. Laemmli, U. K. 1970. Cleavage of structural proteins during the assembly of the head of bacteriophage T4. Nature (Lond.). 227: 680-685.

13. Towbin, H., T. Staehelin, and J. Gordon. 1979. Electrophoretic transfer of proteins from polyacrylamide gels to nitrocellulose sheets: procedure and some applications. Proc. Natl. Acad. Sci. U. S. A. 76: 4350-4354.

14. Lowry, O. H., N. J. Rosebrough, A. L. Farr, and R. J. Randall. 1951. Protein measurement with the Folin phenol reagent. J. Biol. Chem. 193: 265-275.

15. Peterson, M. B., and M. Lesch. 1972. Protein synthesis and amino acid transport in the isolated rabbit right ventricular papillary muscle: effects of isometric tension development. Circ. Res. 31: 317-327.

16. Weber, K., and M. Osborn. 1969. The reliability of molecular weight determinations by dodecyl sulfate-polyacrylamide gel electrophoresis. J. Biol. Chem. 244: 4406-4412.

17. Airhart, J., J. Kelley, J. E. Brayden, R. B. Low, and W. S. Stewart. 1979. An ultramicro method of amino acid analysis: application to studies of protein metabolism in cultured cells. Anal. Biochem. 96: 45-55.

18. Samarel, A. M., E. A. Ogunro, A. G. Ferguson, and M Lesch. 1981. Determination of ${ }^{35} \mathrm{~S}$-aminoacyl-tRNA specific radioactivity in small tissue samples. Anal. Biochem. 118: 155-161.

19. Rannels, D. E., A. E. Pegg, S. R. Rannels, and L. S. Jefferson. 1978. Effect of starvation on initiation of protein synthesis in skeletal muscle and heart. Am. J. Physiol. 235: E126-E133.

20. Hasilik, A., and E. F. Neufeld. 1980. Biosynthesis of lysosomal enzymes in fibroblasts: phosphorylation of mannose residues. J. Biol. Chem. 255: 4946-4950.

21. Wildenthal, K. A., A. R. Poole, and J. T. Dingle. 1975. Influence of starvation on the activities and localization of cathepsin D and other lysosomal enzymes in hearts of rabbits and mice. J. Mol. Cell. Cardiol. 7: 841-855.

22. Decker, R. S., A. R. Poole, and K. Wildenthal. 1980. Distribution of lysosomal cathepsin D in normal, ischemic, and starved rabbit cardiac myocytes. Circ. Res. 46: 485-494.

23. Hasilik, A. 1980. Biosynthesis of lysosomal enzymes. Trends Biochem. Sci. 4: 237-240. 